\title{
Neurological manifestations of Chikungunya and Zika infections
}

\author{
Manifestações neurológicas das infecções pelos vírus Zika e Chikungunya \\ Talys J. Pinheiro', Luis F. Guimarães', Marcus Tulius T. Silva², Cristiane N. Soares ${ }^{1}$
}

\begin{abstract}
The epidemics of Chikungunya virus (CHIKV) and Zika virus (ZIKV) infections have been considered the most important epidemiological occurrences in the Americas. The clinical picture of CHIKV infection is characterized by high fever, exanthema, myalgia, headaches, and arthralgia. Besides the typical clinical picture of $\mathrm{CHIKV}$, atypical manifestations of neurological complications have been reported: meningo-encephalitis, meningoencephalo-myeloradiculitis, myeloradiculitis, myelitis, myeloneuropathy, Guillain-Barré syndrome and others. The diagnosis is based on clinical, epidemiological, and laboratory criteria. The most common symptoms of ZIKV infection are skin rash (mostly maculopapular), fever, arthralgia, myalgia, headache, and conjunctivitis. Some epidemics that have recently occurred in French Polynesia and Brazil, reported the most severe conditions, with involvement of the nervous system (Guillain-Barré syndrome, transverse myelitis, microcephaly and meningitis). The treatment for ZIKV and CHIKV infections are symptomatic and the management for neurological complications depends on the type of affliction. Intravenous immunoglobulin, plasmapheresis, and corticosteroid pulse therapy are options.
\end{abstract}

Keywords: Guillain-Barre syndrome; Zika virus; Chikungunya virus.

\section{RESUMO}

As epidemias provocadas pelo vírus Chikungunya (CHIK) e Zika vírus (ZIKV) têm sido consideradas as ocorrências epidemiológicas mais importantes da América. O quadro clínico da infecção por CHIK caracteriza-se por febre alta, exantema, mialgia, cefaléia e artralgia. Além do quadro clínico típico, manifestações atípicas como complicações neurológicas foram relatadas: meningo-encefalite, mielorradiculopatia, mielorradiculite, mielite, mieloneuropatia, síndrome de Guillain-Barre (GBS), entre outras. O diagnóstico é baseado em critérios clínicos, epidemiológicos e laboratoriais. Em relação aos sinais e sintomas da infecção pelo ZIKV, erupção cutânea (principalmente maculopapular), febre, artralgia, mialgia, cefaléia e conjuntivite são os mais comuns. Algumas epidemias que ocorreram recentemente na Polinésia Francesa e Brasil relataram condições mais severas, com envolvimento do sistema nervoso (GBS, mielite transversa, microcefalia e meningite). 0 tratamento para ZIKV e CHIK é sintomático, e o manejo das complicações neurológicas dependerá do tipo da afecção. Imunoglobulina venosa, plasmaférese, e pulsoterapia com corticosteróides são opções.

Palavras-chave: síndrome de Guillain-Barré; Zika vírus; vírus Chikungunya.

The pandemic of Chikungunya virus (CHIKV) and Zika virus (ZIKV) infection throughout South and Central America is the most important epidemiological occurrence nowadays. High temperatures rates, vector abundance, and inability to control it makes Latin America a high-risk area for the establishment and spread of arbovirus diseases and, as a consequence, their neurological complications. This article focuses on the reemergence of these diseases, their neurological manifestations, and possible treatments.

\section{CHIKUNGUNYA INFECTION}

\section{History and epidemiology}

Chikungunya virus is a member of the Togaviradae family, belonging to the genus alphavirus. It was first isolated from a febrile patient during an outbreak in 1952-1953 in southern Tanzania ${ }^{1}$. The name Chikungunya is derived from the Kimakonde language, meaning "to become contorted" or "that which bends up".

${ }^{1}$ Hospital dos Servidores do Estado, Serviço de Neurologia, Rio de Janeiro RJ, Brasil;

${ }^{2}$ Laboratório de Pesquisa Clínica em Doenças Neuroinfecciosas, Instituto Nacional de Doenças Infecciosas Evandro Chagas/ Fundação Oswaldo Cruz, RJ, Brasil.

Correspondence: Cristiane N. Soares; Rua Santa Clara, 50 / sala 1217; 22060-000 Rio de Janeiro RJ, Brasil; E-mail: crist_nsoares@yahoo.com.br Conflict of interest: There is no conflict of interest to declare.

Received 08 July 2016; Accepted 26 July 2016. 
Three genotypes of CHIKV have been defined: the West African, East/Central/South African, and Asian. The virus can be transmitted in a human-mosquito-human transmission cycle and can be spread by viremic humans. This fact is important as in dense human populations with lack of immunity there is a great probability of an explosive CHIKV epidemic $^{2}$. Aedes (Ae.) aegypti and Ae. albopictus mosquitoes are the vectors for this virus and are found throughout the Americas, including parts of the United States.

Chikungunya virus outbreaks have previously been documented in the countries in Africa, Asia, Europe, India and the Pacific islands ${ }^{3}$. In 2013, the first confirmed autochthonous cases in the Americas were reported on St Martin Island, in the Caribbean. Before that, only imported cases of CHIKV had been detected ${ }^{4}$. As most people in that region are not immune, 3.6 billion persons in 124 countries are estimated to be at risk.

In 2015, several southern American countries confirmed local transmission: Bolivia, Ecuador, Colombia, Paraguay, Venezuela, and Argentina ${ }^{5}$. Brazil had its first indigenous transmission in the state of Amapa in 2014.

New cases of Chikungunya in the Americas were reported during April 2016 making a total count of 41,116 confirmed and suspected cases. Included in the recent increases, Bolivia reported 1,725 new infections, Colombia recorded 967 new cases (10,415 this year), followed by Brazil and Guatemala ${ }^{6}$ (Figure).

\section{Clinical and neurological manifestations}

The incubation period for CHIKV ranges from one to 12 days and is followed by high fever, exanthema, myalgia, headaches, and arthralgia. This last symptom is usually symmetrical and, almost always, affects more than one joint. Although the acute symptoms do not last more than one to two weeks, arthralgia can persist for months or years. Asymptomatic infections rates range from $3 \%$ to $25 \%$ of cases ${ }^{7}$.

Beside the typical clinical picture of CHIKV, atypical manifestations such as neurological complications have been reported. In these cases, the clinical spectrum between adults and children has been similar ${ }^{8}$. Encephalopathy was the most common complication among CHIKV-infected neonates after mother-to-child transmission. During the delivery period, the rate of transmission for viremic women was close to $50 \%$. Fifty percent of infected infants had pathological MRI findings, such as white matter lesions, swelling of the brain, and cerebral hemorrhages, sometimes progressing to permanent disabilities or death ${ }^{9}$.

Meningoencephalitis has been reported in outbreaks in India and Réunion Island ${ }^{10}$. Neurological manifestations secondary to CHIKV infection have been described, ranging from $16 \%$ of a total of 300 cases, with encephalitis being the most common neurological presentation ${ }^{11,12}$. Brainstem encephalitis post-Chikungunya infection had also been reported ${ }^{10}$.

Neurological complications described in the recent epidemics include: meningo-encephalitis, meningoencephalo-myeloradiculitis, myeloradiculitis, myelitis, myeloneuropathy, Guillain-Barré Syndrome (GBS), external ophthalmoplegia, facial palsy, sensori-

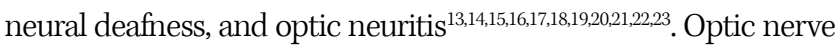
involvement in CHIKV infection includes papillitis, retrobulbar neuritis, and neuroretinitis ${ }^{17}$. Encephalitis occurs either simultaneously or within a few days of onset of systemic symptoms,

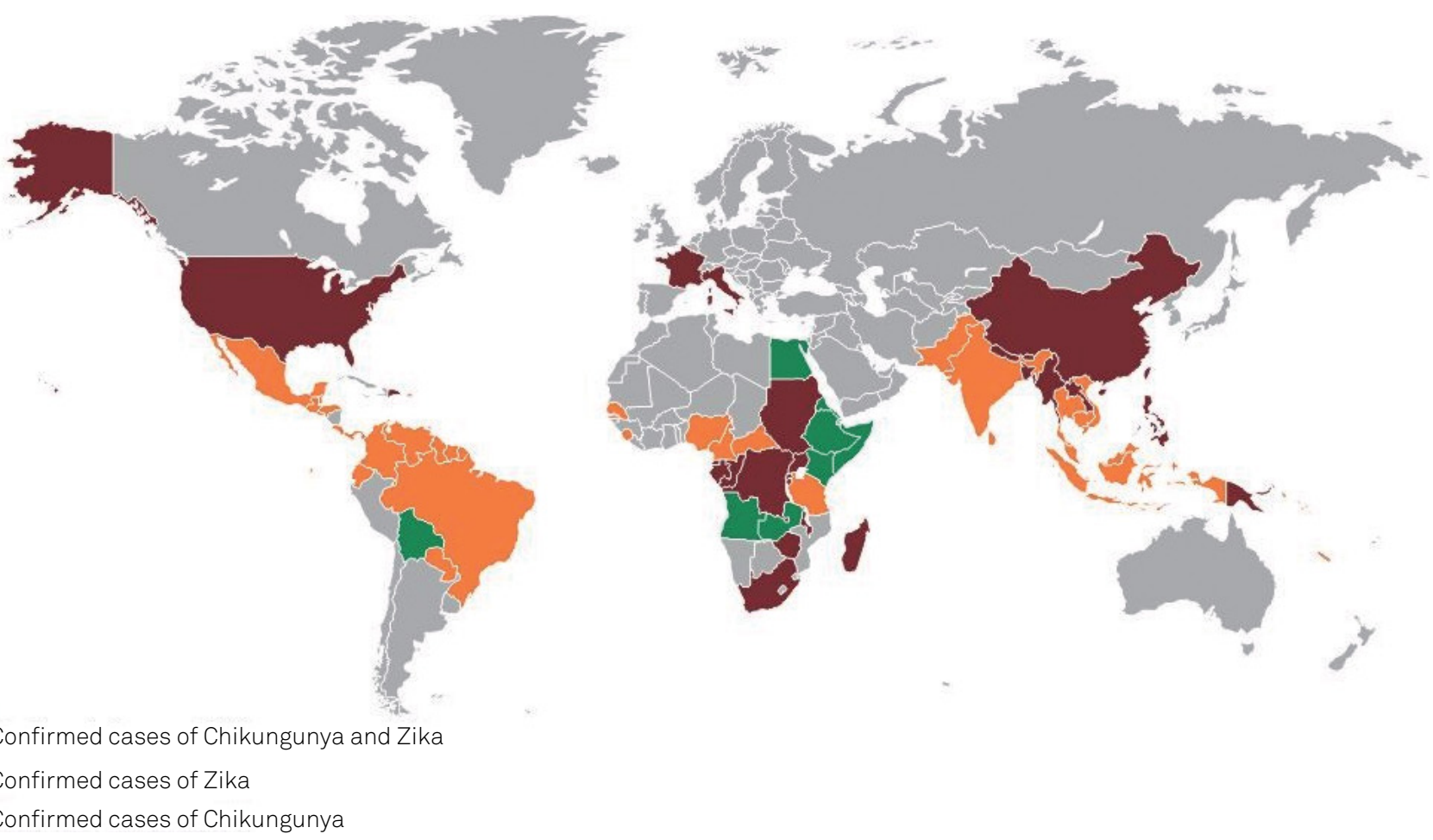

Figure. Confirmed cases of Chikungunya and Zika infections. 
during the period of viremia. A delay of more than two weeks has been reported with other complications like myelitis, GBS, and optic neuritis ${ }^{13,17,21}$.

A prospective study, performed in India from August to October 2006, of 20 hospitalized patients, found the occurrence of neurological symptoms and signs early in the course of the disease in cases of Chikungunya. All patients showed a disturbance in their level of consciousness, such as confusion, drowsiness and delirium. Six patients had psychosis and six had focal or generalized seizures with normal EEG. Total blindness due retro-bulbar neuritis occurred in two patients. One patient had right hemiparesis, with diminished deep tendon reflexes and flexor plantar response, and mild papilloedema. A brain CT scan revealed a ring-enhancing lesion in the left basal ganglia ${ }^{19}$.

Analysis of the cerebrospinal fluid of patients in this study revealed raised protein in 17 patients; glucose was normal in all 20 patients. Nine patients had a cytology count of $>5$ cells $/ \mathrm{mm}^{3}$, predominantly lymphocytes or mononuclear cells, indicating that there was no specific correlation between neurological findings and abnormalities in the cerebrospinal fluid $(\mathrm{CSF})^{19}$ (Table 1).

\section{Neuropathogenesis}

The CHIKV can be detected in the brain within two days of experimental infection ${ }^{30}$. Microgliosis and perivascular cuffs were found in the brain parenchyma of mice infected by CHIKV, as well as neuronal degeneration in the hippocampus and multifocal lymphocytic leptomeningitis. Also, CHIKV seems to targets ependymal cells, progenitor and stem cells in the subventricular zone. This would impair neurogenesis and neuronal migration, and is an hypothesis for the neuropathogenesis of encephalomyelitis related to $\mathrm{CHIKV}^{9}$.

Recent studies have demonstrated that cultured astrocytes and oligodendrocytes are highly susceptible to CHIKV infection. Glial cells express several pattern recognition receptors involved in detecting viral particles as well as damage-associated molecular patterns. These cells can then be induced to express high levels of cytokines and chemokines in response to CHIKV infection. The astrocytes' response to this virus would alter the number and distribution of synapses that each astrocyte would be capable of forming. These results provide the first evidence that CHIKV infection induces morphometric and innate immune activation of astrocytes in vivo ${ }^{31}$.

\section{Laboratory diagnosis}

The diagnosis of CHIKV is based on clinical, epidemiological, and laboratory criteria. The detection of viral nucleic acid or the infectious virus in serum samples is useful during the initial viremic phase, at the onset of symptoms, and usually for the following five to 10 days, when CHIKV RNA reaches very high levels. After this, the diagnosis depends on the detection of specific immune responses by serological methods ${ }^{32,33,34}$.

The molecular assays are a rapid and sensitive technique for the diagnosis of CHIKV infection during the early stages of illness. Conventional reverse transcription polymerase chain reaction (RT-PCR) ${ }^{32}$ are available, along with other RT-PCR real-time assays ${ }^{33}$ More recently, a one-step SYBR

Table 1. Neurological manifestations of ZIKV and CHIK infections.

\begin{tabular}{|c|c|c|c|c|c|}
\hline $\begin{array}{l}\text { Neurological } \\
\text { manifestations }\end{array}$ & Author & $\begin{array}{c}\text { Year of } \\
\text { publication }\end{array}$ & $\begin{array}{l}\text { Number of } \\
\text { confirmed } \\
\text { cases }\end{array}$ & Treatment & Evolution \\
\hline \multicolumn{6}{|l|}{ ZIKV } \\
\hline \multirow[b]{2}{*}{ Guillain-Barré syndrome } & Oehler et al. ${ }^{24}$ & 2014 & 1 & $\begin{array}{c}\text { Intravenous } \\
\text { immunoglobulin }\end{array}$ & Favorable \\
\hline & Lormeau et al. ${ }^{25}$ & 2016 & 42 & $\begin{array}{l}\text { All cases Intravenous } \\
\text { immunoglobulin and one } \\
\text { case plasmapheresis }\end{array}$ & Favorable \\
\hline Acute Myelitis & Mécharles et al. ${ }^{26}$ & 2016 & 1 & $\begin{array}{l}\text { Pulsetherapy with } \\
\text { methylprednisolone }\end{array}$ & Favorable \\
\hline Meningoencephalitis & Carteaux et al. ${ }^{27}$ & 2016 & 1 & No specific treatment & Favorable \\
\hline Microcephaly & Victora et al. ${ }^{28}$ & 2016 & 17 & Not reported & Not reported \\
\hline $\mathrm{CHIK}$ & Cauchem et al. ${ }^{29}$ & 2016 & 8 & Not reported & Not reported \\
\hline Meningoencephalitis & Kalita ${ }^{16}$ & 2012 & 1 & No specific treatment & Favorable \\
\hline \multirow{4}{*}{ Guillain-Barré syndrome } & \multirow{4}{*}{ Wielanek et al. ${ }^{18}$} & \multirow{4}{*}{2007} & \multirow{4}{*}{3} & $\begin{array}{l}\text { Intravenous } \\
\text { immunoglobulin }\end{array}$ & $\begin{array}{l}\text { Severe outcome } \\
\text { Partial recovery }\end{array}$ \\
\hline & & & & None & Partial recovery \\
\hline & & & & \multirow{2}{*}{$\begin{array}{l}\text { Intravenous } \\
\text { immunoglobulin }\end{array}$} & Severe outcome \\
\hline & & & & & Partial recovery \\
\hline Encephalitis & Casolari S et al. ${ }^{14}$ & 2008 & 1 & No specific treatment & Favorable \\
\hline
\end{tabular}


green-based real-time assay targeting the non-structural nsp2 gene has been described ${ }^{34}$.

Virus isolation from the serum of infected patients can also be performed. In the early phase of the disease, the viral load is very high and the immune response is not yet detectable. The presence of an early antibody seems to prevent isolation of the virus, since virus isolation has been shown to be successful largely in antibody-negative samples, obtained on, or before, day two of illness ${ }^{35}$.

Immunological techniques such as IFA and ELISA tests are rapid and sensitive for the detection of specific antibodies for the CHIKV. The IgM antibodies are detectable two to three days after the onset of symptoms and persist for several weeks to three months ${ }^{30}$. Rarely, IgM can be detected for longer periods, up to one year. Type-specific IgG antibodies appear after IgM antibodies (two to three days) and persist for years.

Another test that can be used is the plaque reduction neutralization test. It is quite specific for alphaviruses and is the gold standard for confirmation of serologic results. Its positivity may be more than eight days after the onset of illness $^{36}$ (Table 2).

\section{ZIKA VIRUS}

\section{History and epidemiology}

The ZIKV was first reported on April 18, 1947, when a mysterious fever developed in a rhesus monkey in the Zika Forest of Uganda ${ }^{37}$. The ZIKV was then isolated, using Rhesus serum inoculation in mouse brains.

The virus was isolated from humans in Nigeria during studies conducted in 1968 and during 1971-1975 ${ }^{28}$. From 1951 through 1981, serologic evidence of human ZIKV infection was reported from other African countries such as Uganda, Tanzania, Egypt, Central African Republic, Sierra Leone ${ }^{39}$, Gabon, and in parts of Asia $^{39,40}$. The ZIKV disease was detected outside of Africa and Asia following an outbreak on Yap Island in $2007^{41,42}$.

More recently, in October 2013, ZIKV was detected in French Polynesia ${ }^{43}$. Several cases of ZIKV infections have been reported in travelers to southeast Asia ${ }^{44,45}$ and French Polynesia ${ }^{43,46}$. In early 2015 , the records of patients presenting with a "dengue-like syndrome" appeared in the public health

Table 2. Diagnostics methods according to disease duration.

\begin{tabular}{lcc}
\hline ASSAY & \multicolumn{1}{c}{ ZIKA } & CHIKUNGUNYA \\
\hline PCR serum & Less than 10 days & Less than 10 days \\
PCR in urine & Up to 9 to 12 days & Not applicable \\
ELISA or IFA & After 5 to 6 days & After 2 to 3 days \\
PRNT & After 5 to 6 days & Up to 8 days \\
\hline
\end{tabular}

PCR: polymerase chain reaction; IFA: immunofluorescence assay; PRNT: plaque reduction neutralization test. service in the city of Natal, Rio Grande do Norte, Brazil ${ }^{47}$. The same virus was recognized in February 2015, in Bahia ${ }^{48}$ and São Paulo. Later, ZIKV was also described in Alagoas, Maranhão, Pará, and Rio de Janeiro, showing its ability to disperse $^{41}$. The virus had spread to at least 14 Brazilian states ${ }^{49}$ by December 2015. By March 2016, a total of 51,473 suspected cases of ZIKV had been reported (Figure).

In fact, the real incidence of Zika fever is unknown due clinical symptoms that mimic dengue infection, and the lack of simple laboratory tests. However, in endemic areas, epidemiological studies have shown a high prevalence of antibodies against Zika ${ }^{38}$. An example of this is the Yap epidemic that occurred in 2007, resulting in an attack rate of 14.6/1000 inhabitants and a seroprevalence of $75 \%$ after the epidemic. This prevalence is certainly overestimated due to cross-reactivity between antibodies directed against Zika and other arboviruses ${ }^{41,50}$.

The ZIKV is an RNA virus, belonging to the Flaviviridae family. It has been isolated from mosquitoes Ae. africanus, Ae. apicoargenteus, Ae. luteocephalus, Ae. aegypti, Ae vitattus, and Ae. Furcifer ${ }^{38,51}$. Boorman, et al. showed that the extrinsic incubation period for ZIKV in mosquitoes is approximately 10 days and the ZIKV is transmitted through mosquito bites ${ }^{52}$.

\section{Clinical and neurological manifestations}

The most common signs and symptoms of ZIKV infection are skin rash (mostly maculopapular), fever, arthralgia, myalgia, headache, and conjunctivitis. Other symptoms such as articular oedema, sore throat, cough, and vomiting are also reported ${ }^{45,53}$.

Despite the generally benign course of the disease, some epidemics that recently occurred in French Polynesia and Brazil reported the most severe conditions with involvement of the nervous system (GBS, transverse myelitis, microcephaly and meningitis). During the Zika outbreak in French Polynesia, the first case of GBS developed seven days after a flu-like illness, bringing to mind Zika infection. Since then, the incidence of GBS has multiplied 20-fold in French Polynesia, raising the possibility of a potential implication of ZIKV ${ }^{24}$.

It has been found that the simultaneous epidemics of dengue virus type 1 and 3 could also be a predisposing factor for the development of GBS during Zika fever, since infection by the dengue virus had also been associated with GBS $^{54,55}$. This fact raised the possibility of an immune stimulation by sequential arboviruses that could be responsible for such an unusual clustering of GBS cases during simultaneous Zika infection and two dengue serotypes. The risk of GBS development would be increased by a specific sequence of dengue virus infections and Zika. Hence, in endemic areas, physicians should be aware of the risk of demyelinating diseases in cases of Zika infection.

In a Polynesia Epi Bulletin there were neurological or autoimmune complications found in 70 patients 
studied between November 2013 and February, 2014 ${ }^{56}$. Thirty-eight patients had GBS after ZIKV infection and 25 had other neurological complications such as encephalitis, meningoencephalitis-encephalitis, facial paralysis, and myelitis. Among the GBS patients, there were $73 \%$ males, with a mean age of 45.9 years, and almost all cases were ethnic Polynesians. All the patients with GBS developed neurological symptoms after the development of a disease with symptoms consistent with ZIKV infection in previous days. One of these patients had been laboratory-confirmed as ZIKV by RT-PCR at the initial infection, and other preliminary results showed ZIKV IgG positive after the occurrence of neurological signs ${ }^{56}$.

A GBS case-controlled study performed at the Hospital of Polynésie Française during the outbreak period (between October 2013 and April 2014), suggested a possible association between the ZIKV and GBS. According to the study, 42 patients were diagnosed with GBS during the period, where 41 (98\%) of these patients had ZIKV anti-IgM or IgG. Patients with GBS had electrophysiological findings consistent with acute motor axonal neuropathy, characterized by the distal involvement of motor nerves. The recovery was faster than normally observed in typical GBS ${ }^{25}$.

The ZIKV was also found in the cerebrospinal fluid of a 15-year-old patient, hospitalized in Pointe-à-Pitre, Guadaloupe, in January 2016. He presented with an acute myelitis, suggesting that the virus is neurotropic and it should be considered in patients living in, or traveling to, endemic areas ${ }^{26}$.

Carteaux, et al. described a case of an 81-year-old man who presented with a decreased level of consciousness, left hemiplegia and paresis of the right upper limb. There was a history of a transient rash 48 hours before the neurological symptoms. Brain MRI and CSF analysis were suggestive of meningoencephalitis. The PCR for ZIKV was positive in the CSF, supporting the diagnosis of ZIKV-associated meningoencephalitis ${ }^{27}$.

The Brazilian Ministry of Health, in November 2015, declared a public health emergency concerning an abnormal increase of children born with microcephaly during 2015, in the state of Pernambuco. Until that date, 141 cases of microcephaly in newborns had been reported in the same state, compared with an average of 10 cases per year from 2010-2014 ${ }^{57}$. An increase was also reported in the states of Paraíba and Rio Grande do Norte. Later, in the same year, the Ministry of Health reported the presence of ZIKV RNA detected by RT-PCR in amniotic fluid samples, collected from two pregnant women. Their babies presented with microcephaly ${ }^{57}$ and these women had symptoms compatible with ZIKV infection during pregnancy. Between mid-2015 and January 2016, there were 4,783 cases of suspected microcephaly, 387 cases had brain abnormalities found on imaging, and ZIKV was detected in 17 babies $^{28}$.

During a retrospective analysis of a large Zika outbreak in French Polynesia, between 2013 and 2014, the authors found that the risk of malformation was about $1 \%$ when women were infected by the ZIKV during the first trimester of pregnancy ${ }^{29}$. It had become a major public health concern, as the incidence of Zika virus in the general population may be very high during outbreaks. Thus, these findings highlight the need to inform pregnant women to protect themselves from mosquito bites and avoid traveling to affected countries ${ }^{29}$.

\section{Diagnostic methods}

The ZIKV infection can be diagnosed by PCR, which can detect viral RNA, in the acute phase. Samples obtained within 10 days after the onset of the disease should have PCR performed. In general, the diagnostic tests for flaviviruses should include an acute phase serum sample, taken as soon as possible after the onset of disease and a second sample taken two to three weeks after the first ${ }^{58}$.

Other diagnostic methods include serologic tests (ELISA or immunofluorescence) to detect IgM or IgG antibodies against ZIKV, which may be positive after five to six days after the onset of symptoms. This should show an increase of antibody titer in paired samples with an interval of about two weeks. Confirmation of the positive results should be confirmed with the plaque reduction neutralization test, showing at least a fourfold increase in titer of neutralizing antibodies to ZIKV. It is known that cross-reactivity with other flaviviruses can occur, especially dengue, yellow fever and, less frequently, with the West Nile virus. Therefore, the results should be interpreted with caution ${ }^{37,38}$. Urine samples for the detection of viral genomes by RT-PCR may be the diagnostic method of choice, since the disappearance of the genome in serum has been shown to be within 10 days for ZIKV, but in urine samples it can be detected until fifteen days after the onset of infection ${ }^{58,59,60}$ (Table 2).

Appropriate diagnostic specimens for RT-PCR testing include plasma/serum, urine, CSF, amniotic fluid and placental tissue. Serology is usually performed on serum; however, viral antibodies may also be detected in the $\operatorname{CSF}^{58,59,60}$.

\section{Chikungunya and Zika treatment}

Treatment for Zika and CHIKV is symptomatic, and is very similar to dengue fever. It includes antipyretic, analgesic, anti-inflammatory drugs to reduce joint and muscle pain, three to six eye drops twice daily as a lubricant, anti-allergy drugs, among others. In the case of pruritic eruptions, antihistamines may be considered. Medicines containing aspirin should not be used, as well as in cases of dengue fever, because they may increase the risk of bleeding ${ }^{61}$.

The treatment of neurological manifestations will depend on the type of affliction, such as intravenous immunoglobulin or plasmapheresis in cases of $\mathrm{GBS}^{25}$, and corticosteroid pulse therapy/intravenous immunoglobulin in cases of myelitis ${ }^{26}$.

There is no vaccine against these diseases. The Aedes mosquito outbreaks, typical of urban areas of tropical and subtropical climates, should be eliminated. 
1. Gutierrez-Saravia E, Gutierrez CE. Chikungunya virus in the Caribbean: a threat for all of the Americas. J Pediatric Infect Dis Soc. 2015;4(1):1-3. doi:10.1093/jpids/piv002

2. Morrison TE. Reemergence of chikungunya virus. J Virol. 2014;88(20):11644-7. doi:10.1128/JVI.01432-14

3. Garg M, Alcalde V. Update on emerging infections: news from the centers for disease control and prevention. Ann Emerg Med. 2014;64(5):553-5. doi:10.1016/j.annemergmed.2014.07.456

4. Halstead SB. Reappearance of chikungunya, formerly called dengue, in the Americas. Emerg Infect Dis. 2015;;21(4):557-61. doi:10.3201/eid2104.141723

5. Carbajo AE, Vezzani D. Waiting for chikungunya fever in Argentina: spatio-temporal risk maps. Mem Inst Oswaldo Cruz. 2015;110(2):259-62. doi:10.1590/0074-02760150005

6. Pan American Health Organization - PAHO. Cases of Chikungunya Fever in the Americas, 2016 (for week). Washington, DC: Pan American Health Organization; 2016 [acess 2016 Apr 8]. Available from: http://www.paho.org/hq/index.php?option=com_ docman\&task=doc_view\&ltemid $=\&$ gid $=34132 \&$ lang $=$ en

7. Burt FJ, Rolph MS, Rulli NE, Mahalingam S, Heise MT. Chikungunya: a re-emerging virus. Lancet. 2012;379(9816):662-71. doi:10.1016/S0140-6736(11)60281-X

8. Azevedo RS, Oliveira CS, Vasconcelos PF. Chikungunya risk for Brazil. Rev Saúde Pública. 2015;49:58. doi:10.1590/S0034-8910.2015049006219

9. Das T, Jaffar-Bandjee MC, Hoarau JJ, Krejbich Trotot P, Denizot M, Lee-Pat-Yuen G et al. Chikungunya fever: CNS infection and pathologies of a re-emerging arbovirus. Prog Neurobiol. 2010;91(2):121-9. doi:10.1016/j.pneurobio.2009.12.006

10. Gauri LA, Ranwa BL, Nagar K, Vyas A, Fatima Q. Post chikungunya brain stem encephalitis. J Assoc Physicians India. 2012;60:68-70.

11. Rampal SM, Meena H. Neurological complications in Chikungunya Fever. J Assoc Physicians India. 2007;55:765-9.

12. Chandak NH, Kashyap RS, Taori GM, Daginawala HF. Neurological complications in Chikungunya infection. BMC Proc. 2008;2 Suppl 1:11. doi:10.1186/1753-6561-2-s1-p11

13. Wadia RS. A neurotropic virus (chikungunya) and a neuropathic aminoacid (homocysteine). Ann Indian Acad Neurol. 2007;10:198-213.

14. Casolari S, Briganti E, Zanotti M, Zauli T, Nicoletti L, Magurano F et al. A fatal case of encephalitis associated with Chikungunya virus infection. Scand J Infect Dis. 2008;40(11-12):995-6. doi:10.1080/00365540802419055

15. Lalitha P, Rathinam S, Banushree K, Maheshkumar S, Vijayakumar R, Sathe P. Ocular involvement associated with an epidemic outbreak of chikungunya virus infection. Am J Ophthalmol. 2007;144(4):552-6. doi:10.1016/j.ajo.2007.06.002

16. Kalita J, Kumar P, Misra UK. Stimulus-sensitive myoclonus and cerebellar ataxia following chikungunya meningoencephalitis. Infection. 2013;41(3):727-9. doi:10.1007/s15010-013-0406-2

17. Mittal A, Mittal S, Bharati MJ, Ramakrishnan R, Saravanan S, Sathe PS. Optic neuritis associated with chikungunya virus infection in south India. Arch Ophthalmol. 2007;125(10):1381-6. doi:10.1001/archopht.125.10.1381

18. Wielanek AC, Monredon JD, Amrani ME, Roger JC, Serveaux JP. Guillain-Barré syndrome complicating a Chikungunya virus infection. Neurology. 2007;69(22):2105-7. doi:10.1212/01.wnl.0000277267.07220.88

19. Rampal S, Sharda M, Meena H. Neurological complications in Chikungunya fever.J Assoc Phys India. 2007;55:765-9.

20. Robin D, Le Seach F, Jaffar-Bandjee MC, Rigou G, Alessandri JL. Neurologic manifestations of pediatric chikungunya infection. J Child Neurol. 2008;23(9):1028-35. doi:10.1177/0883073808314151
21. Chandak NH, Kashyap RS, Kabra D, Karandikar P, Saha SS, Morey $\mathrm{SH}$ et al. Neurological complications of Chikungunya virus infection. Neurol India. 2009;57(2):177-80. doi:10.4103/0028-3886.51289

22. Lemant J, Boisson V, Winer A, Thibault L, André H, Tixier F et al. Serious acute chikungunya virus infection requiring intensive care during the Reunion Island outbreak in 2005-2006. Crit Care Med. 2008;36(9):2536-41. doi:10.1097/CCM.0b013e318183f2d2

23. Bhavana K, Tyagi I, Kapila RK. Chikungunya virus induced sudden sensorineural hearing loss. Int J Pediatr Otorhinolaryngol. 2008;72(2):257-9. doi:10.1016/j.ijporl.2007.09.022

24. Oehler E, Watrin L, Larre P, Leparc-Goffart I, Lastere S, Valour F et al. Zika virus infection complicated by Guillain-Barre syndrome: case report, French Polynesia, December 2013. Euro Surveill. 2014;19(9):20720. doi:10.2807/1560-7917.ES2014.19.9.20720

25. Cao-Lormeau VM, Blake A, Mons S, Lastère S, Roche C, Vanhomwegen J et al. Guillain-Barré Syndrome outbreak associated with Zika virus infection in French Polynesia: a case-control study. Lancet. 2016;387(10027):1531-9. doi:10.1016/S0140-6736(16)00562-6

26. Mécharles S, Herrmann C, Poullain P, Tran TH, Deschamps N, Mathon $\mathrm{G}$ et al. Acute myelitis due to Zika virus infection. Lancet. 2016;387(10026):1481. doi:10.1016/S0140-6736(16)00644-9

27. Carteaux G, Maquart M, Bedet A, Contou D, Brugières P, Fourati $S$ et al. Zika virus associated with meningoencephalitis. N Engl J Med. 2016;374(16):1595-6. doi:10.1056/NEJMc1602964

28. Victora CG, Schuler-Faccini L, Matijasevich A, Ribeiro E, Pessoa A, Barros FC. Microcephaly in Brazil: how to interpret reported numbers? Lancet. 2016;387(10019):621-4. doi:10.1016/S0140-6736(16)00273-7

29. Cauchemez S, Besnard M, Bompard P, Dub T, Guillemette-Artur P, Eyrolle-Guignot D et al. Association between Zika virus and microcephaly in French Polynesia, 2013-15: a retrospective study. Lancet. 2016;387(10033):2125-32. doi:10.1016/S0140-6736(16)00651-6

30. Fraisier C, Koraka P, Belghazi M, Bakli M, Granjeaud S, Pophillat $\mathrm{M}$ et al. Kinetic analysis of mouse brain proteome alterations following Chikungunya virus infection before and after appearance of clinical symptoms. PLoS One. 2014;9(3):e91397. doi:10.1371/journal.pone.0091397

31. Inglis FM, Lee KM, Chiu KB, Purcell OM, Didier PJ, Russell-Lodrigue $K$ et al. Neuropathogenesis of Chikungunya infection: astrogliosis and innate immune activation. J Neurovirol. 2016;22(2):140-8. doi:10.1007/s13365-015-0378-3

32. Hasebe F, Parquet C, Pandey BD, Mathenge EG, Morita K, Balasubramaniam $V$ et al. Combined detection and genotyping of Chikungunya virus by a specific reverse transcription-polymerase chain reaction.J Med Virol. 2002;67(3):370-4. doi:10.1002/jmv.10085

33. Carletti F, Bordi L, Chiappini R, Ippolito G, Sciarrone MR, Capobianchi MR et al. Rapid detection and quantification of Chikungunya virus by a one-step reverse transcription polymerase chain reaction real- time assay. Am J Trop Med Hyg. 2007;77(3):521-4.

34. Ho PS, Ng MM, Chu JJ. Establishment of one-step SYBR green-based real time-PCR assay for rapid detection and quantification of chikungunya virus infection. Virol J. 2010;7(1):13. doi:10.1186/1743-422X-7-13

35. Panning M, Grywna K, Esbroeck M, Emmerich P, Drosten C. Chikungunya fever in travelers returning to Europe from the Indian Ocean region, 2006. Emerg Infect Dis. 2008;14(3):416-22. doi:10.3201/eid1403.070906

36. Litzba N, Schuffenecker I, Zeller H, Drosten C, Emmerich P, Charrel R et al. Evaluation of the first commercial chikungunya virus indirect immunofluorescence test. J Virol Methods. 2008;149(1):175-9. doi:10.1016/j.jviromet.2008.01.004 
37. Dick GW, Kitchen SF, Haddow AJ. Zika virus. I. Isolations and serological specificity. Trans R Soc Trop Med Hyg. 1952;46(5):509-20. doi:10.1016/0035-9203(52)90042-4

38. Fagbami AH. Zika virus infections in Nigeria: virological and seroepidemiological investigations in Oyo State. J Hyg (Lond). 1979;83(2):213-9. doi:10.1017/S0022172400025997

39. Robin Y, Mouchet J. [Serological and entomological study on yellow fever in Sierra Leone]. Bull Soc Pathol Exot Filiales. 1975;68(3):249-58. French.

40. Olson JG, Ksiazek TG. Suhandiman T. Zika virus, a cause of fever in Central Java, Indonesia. Trans R Soc Trop Med Hyg. 1981;75(3):389-93. doi:10.1016/0035-9203(81)90100-0

41. Lanciotti RS, Kosoy OL, Laven JJ, Velez JO, Lambert AJ, Johnson AJ et al. Genetic and serologic properties of Zika virus associated with an epidemic, Yap State, Micronesia, 2007. Emerg Infect Dis. 2008;14(8):1232-9. doi:10.3201/eid1408.080287

42. Duffy MR, Chen TH, Hancock WT et al. Zika virus outbreak on Yap Island, Federated States of Micronesia. N Engl J Med. 2009;360(24):2536-43. doi:10.1056/NEJMoa0805715

43. Baronti C, Piorkowski G, Charrel RN, Boubis L, Leparc-Goffart I, Lamballerie X. Complete coding sequence of zika virus from a French polynesia outbreak in 2013. Genome Announc. 2014;2(3):e00500-14. doi:10.1128/genomeA.00500-14

44. Fonseca K, Meatherall B, Zarra D, Drebot M, MacDonald J, Pabbaraju K et al. First case of Zika virus infection in a returning Canadian traveler. Am J Trop Med Hyg. 2014;91(5):1035-8. doi:10.4269/ajtmh.14-0151

45. Kwong JC, Druce JD, Leder K. Zika virus infection acquired during brief travel to Indonesia. Am J Trop Med Hyg. 2013;89(3):516-7. doi:10.4269/ajtmh.13-0029

46. Wæhre T, Maagard A, Tappe D, Cadar D, Schmidt-Chanasit J. Zika virus infection after travel to Tahiti, December 2013. Emerg Infect Dis. 2014;20(8):1412-4. doi:10.3201/eid2008.140302

47. Zanluca C, Melo VC, Mosimann AL, Santos GI, Santos CN, Luz K. First report of autochthonous transmission of Zika virus in Brazil. Mem Inst Oswaldo Cruz. 2015;110(4):569-72. doi:10.1590/0074-02760150192

48. Campos GS, Bandeira AC, Sardi SI. Zika virus outbreak, Bahia, Brazil. Emerg Infect Dis. 2015;21(10):1885-6. doi:10.3201/eid2110.150847

49. World Health Organization. Zika virus outbreaks in the Americas. Wkly Epidemiol Rec. 2015;90(45):609-10.
50. Faye O, Dupressoir A, Weidmann M, Ndiaye M, Alpha Sall A. One-step RT-PCR for detection of Zika virus. J Clin Virol. 2008;43(1):96-101. doi:10.1016/j.jcv.2008.05.005

51. Marchette NJ, Garcia R, Rudnick A. Isolation of Zika virus from Aedes aegypti mosquitoes in Malaysia. Am J Trop Med Hyg. 1969;18(3):411-5

52. Boorman JP, Porterfield JS. A simple technique for infection of mosquitoes with viruses; transmission of Zika virus. Trans R Soc Trop Med Hyg. 1956;50(3):238-42. doi:10.1016/0035-9203(56)90029-3

53. Heang V, Yasuda CY, Sovann L, Haddow AD, Travassos da Rosa AP, Tesh RB et al. Zika virus infection, Cambodia, 2010. Emerg Infect Dis. 2012;18(2):349-51. doi:10.3201/eid1802.111224

54. Carod-Artal FJ, Wichmann O, Farrar J, Gascón J. Neurological complications of dengue virus infection. Lancet Neurol. 2013;12(9):906-19. doi:10.1016/S1474-4422(13)70150-9

55. Oehler E, Le Henaff O, Larre P Ghawche F. [Guillain-Barre syndrome following type 4 dengue in Polynesia]. Med Trop (Mars). 2011;71(2):203-4. French.

56. Polynesie Française. Surveillance de la dengue et du zika en Polynésie Française 2014 [acess 2014 Feb 7]. Available from: http:// www.hygiene-publique.gov.pf/spip.php?article120

57. Ministério da Saúde (BR). Microcefalia: Ministério da Saúde divulga boletim epidemiológico. Brasília: Ministério da Saúde; 2015 [acess 2015 Nov 17]. Available from: http://portalsaude.saude.gov.br/index. php/cidadao/principal/agencia-saude/20805-ministerio-da-saudedivulga-boletim-epidemiologico

58. Kutsuna S, Kato Y, Takasaki T, Moi M, Kotaki A, Uemura H et al. Two cases of Zika fever imported from French Polynesia to Japan, December to January 2013. Eurosurveillance. 2014;19(4):20683. doi:10.2807/1560-7917.ES2014.19.4.20683

59. Domingo C, Yactayo S, Agbenu E, Demanou M, Schulz AR, Daskalow K et al. Detection of yellow fever 17D genome in urine. J Clin Microbiol. 2011;49(2):760-2. doi:10.1128/JCM.01775-10

60. Barzon L, Pacenti M, Franchin E, Pagni S, Martello T, Cattai M et al. Excretion of West Nile virus in urine during acute infection.J Infect Dis. 2013;208(7):1086-92. doi:10.1093/infdis/jit290

61. Ministério da Saúde - CIEVS Nacional - Centro de Informações Estratégicas em Vigilância em Saúde - Nota Informativa 07/2015 - Evento de Saúde Pública (ESP) relacionado a casos de síndrome exantemática em estados da Região Nordeste do Brasil em 2015. 